\title{
The investigation of Cryptosporidium spp. in water samples by PCR
}

\section{Su örneklerinde PCR ile Cryptosporidium spp. varlığının araştırılması}

\author{
Semra Özçelik ${ }^{1}$, Erdoğan Malatyalı ${ }^{2}$, Ahmet Alim ${ }^{3}$, Serpil Değerli ${ }^{1}$ \\ ${ }^{\mathrm{T}}$ Department of Parasitology, Cumhuriyet University School of Medicine, Sivas, Turkey \\ ${ }^{2}$ Department of Parasitology, Adnan Menderes University School of Medicine, Aydin, Turkey \\ ${ }^{3}$ Department of Microbiology, Cumhuriyet University School of Pharmacy, Sivas \\ Corresponding author: Dr. Semra Özçelik, Parazitoloji Anabilim Dalı, Cumhuriyet Üniversitesi Tıp Fakültesi, TR-58140, \\ Sivas, Türkiye. \\ E-mail: serpildegerli@yahoo.com \\ Received/Accepted: June 02, 2015/August 29, 2015 \\ Conflict of interest: There is not a conflict of interest. \\ *This work was supported by The Head of Scientific Research Project of Cumhuriyet University, Sivas, Turkey (CUBAP \\ T-393)
}

\section{SUMMARY}

Objective: Cryptosporidium spp. are intestinal pathogens of humans and animals. Environmental and tap water samples obtained from different regions in Sivas were examined for the prevalence of Cryptosporidium infection.

Methods: Approximately $10 \mathrm{lt}$ of water collected and filtered from spring and tap waters from villages and towns in Sivas province were examined. All samples were examined both with the Modified Acid Fast (MAF) staining method and PCR for the presence of Cryptosporidium spp. A genus specific PCR assay was designed for the specific amplification of the 18S SSU rRNA gene. Results: None of the 92 water samples analyzed by MAF were positive, whoever 2 water samples $(2.2 \%)$ from the Kangal and Suşehri counties were positive by PCR.

Conclusions: The PCR technique is more reliable in diagnosing Cryptosporidium in water samples. It is possible that the oocysts are decomposed in water and it is difficult to identify them by MAF.

Keywords: PCR, Cryptosporidium, water, MAF, Sivas, Turkey

\section{ÖZET}

Amaç: Sivas ve çevresinde insanlarda, insanlara kaynak olușturan insan ve hayvan çıartılarıyla kirlenme olasılığı yüksek içme ve kullanma sularında bu parazitin prevalansını PCR yöntemiyle saptamaktir.

Yöntem: Bu amaçla; Sivas ilçe ve köylerinden toplam 92 örnekten en az 10 litrelik su örneği plastik bidonlarla toplanmıș ve filtre edilmiștir. Modifiye Asit Fast (MAF) boyama yöntemi için yayma preparatları hazırlanmış ve 100x'lik objektifle Cryptosporidium spp. yönünden incelenmiştir. Tüm örneklerden DNA izolasyonu ticari bir kit (QIAGEN - QIAamp DNA Stool Mini Kit) kullanılarak yapıldı. Örneklerde Cryptosporidium 18S SSU rRNA lokusunun PCR ile çoğaltılması sonucu tanıya gidilmiştir.

Bulgular: İncelenen 92 su örneğinin asit-fast ile hiç birinde PCR ile 2'sinde (\%2,2) Cryptosporidium spp. saptanmıştır. Pozitif örnekler musluk sularından saptanmış olup kaynak sularında parazit bulunmamıştır. Pozitif örnekler Kangal ve Suşehri ilçelerine bağlı iki köyden elde edilen musluk sularından saptanmıştır.

Sonuç: Çevresel su örneklerinde Cryptosporidium varlığı birkaç yöntemle araştırılmalıdır. Direkt ve Asit-fast boyama yöntemiyle yapilan incelemeler başarılı bulunmamıştır. Çünkü su örneklerinde ookistlerin yapısal özellikleri bozulmakta ve tanınmaları zorlaşmaktadır. Cryptosporidium spp.'nin saptanmasinda PCR daha duyarlı bir yöntemdir.

Anahtar sözcükler: Cryptosporidium spp., PCR, su 


\section{INTRODUCTION}

Cryptosporidium spp. has been recognized as a cause of acute gastroenteritis and diarrhea in immunocompromised and healthy individuals ${ }^{1}$. There are two species of Cryptosporidium, which are pathogenic to humans: C. parvum and C. hominis ${ }^{2}$. Other species of Cryptosporidium are known to cause infections in domestic and wild animals ${ }^{3}$. Cryptosporidium spp. are transmitted to humans via consumption of contaminated water and food but also by direct contact with infected hosts. A marked increase in the incidence of cryptosporidiosis associated with the contamination of environmental water with human and animal feces has been reported ${ }^{1-5}$, while cases of co-infection with Giardia intestinalis have been also described ${ }^{6-9}$. The first outbreak of human cryptosporidiosis is reported from United States in 1984, and later from several other countries worldwide ${ }^{10-14}$. The conventional chlorination of water is inefficient for cryptosporidiosis. A few oocysts taken by drinking water are capable in causing cryptosporidiosis, therefore, it is necessary to apply sensitive technics for the surveillance of this parasite in the environment. Methods such as filtration, sucrose gradient, and immunomagnetic separation to concentrate of Cryptosporidium oocysts from water have been used in recent years ${ }^{15,16}$. Direct Fluorescent Antibody (DFA), Enzyme Linked Immunosorbent Assay (ELISA) and polymerase chain reaction (PCR) methods have been used for detection of Cryptosporidium spp. ${ }^{17-21}$. The $18 \mathrm{~S}$ rRNA genes show a $99 \%$ similarity between Cryptosporidium spp. and primers have been used for the detection of this parasite ${ }^{22}$.

In the present study the presence and prevalence of Cryptosporidium spp. in water samples of Sivas by MAF and PCR methods was aimed.

\section{MATERIAL AND METHODS}

Study Location: A total of 92 water samples were collected from the districts of Gürün $(\mathrm{n}=4)$, Gemerek $(\mathrm{n}=1)$, Kangal $(n=30)$, Akıncilar $(n=2)$, Gölova $(n=4)$, Ulaş ( $n=6)$, Suşehri $(n=23)$, Şarkışla $(n=3)$ and Center county $(n=19)$ of Sivas prov- ince, located in the central Anatolian region of Turkey.

Cryptosporidium control stocks: Unpurified Cryptosporidium oocysts were obtained from a calf fecal suspension. Oocysts were purified from fecal samples by sugar flotation method and stored at $-20^{\circ} \mathrm{C}$.

Collection of water samples and filtration: Overall, 83 tap water and 9 spring water samples were examined. Ten liters of water were taken in sterile containers and filtered using $0.45 \mu \mathrm{l}$ pore sized cellulose acetate membrane filter with vacuum pumping (Sartorius AG, Goettingen, Germany). The filters were transferred to vials with $10 \mathrm{~mL}$ sterile PBS overnight, thereafter they were centrifuged at 2,000 rpm for 5 min. The supernatant was removed, and the pellet was stored for examination by MAF and PCR techniques.

Microscopic examination: All samples were examined by MAF technique under light microscope (Nicon Eclipse E200, Japan) at 100x.

Detection of Cryptosporidium by PCR: DNA extraction was performed using the QIAGEN-QIAamp DNA Stool Mini Kit (Qiagen GmbH, Hidden, Germany) according to the manufacturer's instructions. Prior to DNA extraction samples were frozen and thawed 5 times for $30 \mathrm{~min}$ at $80^{\circ} \mathrm{C}$ and $10 \mathrm{~min}$ at $56 \circ \mathrm{C}$. The resulting DNA samples were stored at $4 \mathrm{oC}$ and used for PCR, thereafter the PCR samples were stored at $-20^{\circ} \mathrm{C}$.

Amplification of Cryptosporidium $18 \mathrm{~S}$ SSU rRNA locus by PCR: PCR was performed according to the protocol of Xiao et $\mathrm{al}^{22}$. For the first PCR reaction $1 \mu \mathrm{l}$ DNA was used. For the next step, a product that was about $1.325 \mathrm{bp}$ long was amplified by using the following primers: $\mathrm{F} 1$ : 5'-TTCTAGAGCTAATACATGCG-3'. R1:5'-CCCATTTCCTTCGAAACAGGA3'. Each PCR mixture (total volume, 100 $\mu \mathrm{L}$ ) contained $10 \mu \mathrm{L}$ of $10 \mathrm{x}$ PCR buffer, primers at a concentration of $200 \mathrm{nM}, 6$ $\mathrm{mM} \mathrm{MgCl2}$, deoxynucleoside triphosphate at a concentration of $200 \mu \mathrm{L}, 2.5 \mathrm{U}$ of Taq polymerase, and $1 \mu \mathrm{L}$ of DNA template. The amplification reactions were run according to the following PCR program: An 
initial step at $94^{\circ} \mathrm{C}$ for $4 \mathrm{~min} ; 35$ cycles of $94^{\circ} \mathrm{C}$ for $45 \mathrm{~s}, 55^{\circ} \mathrm{C}$ for $45 \mathrm{~s}, 72^{\circ} \mathrm{C}$ for 60 $\mathrm{s}$; and $72^{\circ} \mathrm{C}$ for $7 \mathrm{~min}$.

For the secondary PCR step, a PCR product that was 823 bp long was amplified by using $2 \mu \mathrm{L}$ of the primary PCR product and primers (F2: 5'- GGAAGGGTTGTATTTATTAGATAAAG. R2: 5'CTCATAAGGTGCTGAAGGAGTA-3').

The PCR mixture were identical to the conditions used for the primary PCR step, except that an initial hot start at $94^{\circ} \mathrm{C}$ for 3 min was included.

The PCR products were stored at $-20^{\circ} \mathrm{C}$. PCR products were run on $1.5 \%$ agarose gel and visualized by ethidium bromide. In this process a positive control and $50 \mathrm{bp}$ marker (Biomatik DNA Ladder Plus) were used.

Table 1: Districts of sample collection and PCR results.

\begin{tabular}{l|ll}
\hline Districts of sample collection & \multicolumn{2}{|l}{ PCR+\% } \\
\hline Gürün $(n=4)$ & 0 & 0 \\
Gemerek $(n=1)$ & 0 & 0 \\
Kangal $(n=30)$ & 1 & 3.3 \\
Akıncılar $(n=2)$ & 0 & 0 \\
Gölova $(n=4)$ & 0 & 0 \\
Ulaş $(n=6)$ & 0 & 0 \\
Suşehri $(n=23)$ & 1 & 4.3 \\
Şarkışla $(n=3)$ & 0 & 0 \\
Center $(n=19)$ & 0 & 0 \\
\hline Total $(n=92)$ & 2 & 2.2 \\
\hline
\end{tabular}

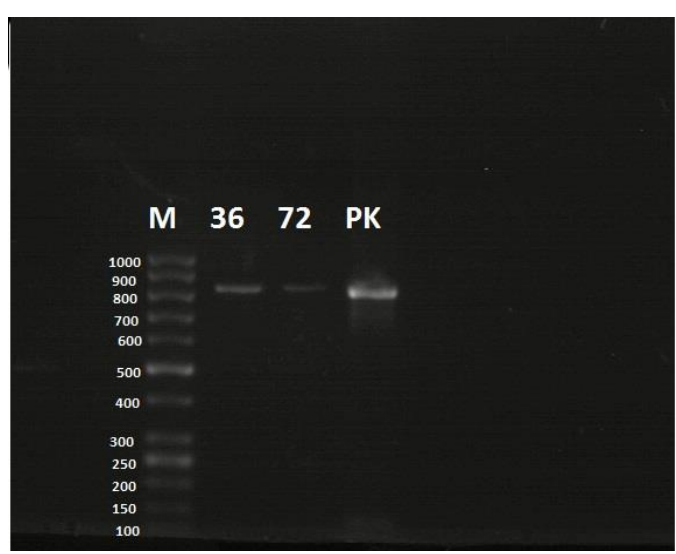

Figure 1: Agarose gel electrophoresis of Nested PCR products.

\section{RESULTS}

Out of 92 samples examined Cryptosporidium spp. were found in one tap water sample of the Kangal and Suşehri counties, each by PCR method (Figure 1), while all examinations by MAF were negative (Table 1).

Lane 1, Molecular weight marker $(1,000$ bp), Lane 2 and 3, Cryptosporidium spp. positive water samples 36 and 72); Lane 4, positive control.

\section{DISCUSSION}

Cryptosporidium spp. have been found in animals such as sheep, cattle, birds, fish and reptiles belonging to 79 species. While some species are adapted to a specific host, others survive in several hosts. The first human case of cryptosporidiosis was reported in 1976. Cryptosporidiosis can be fatal, especially in immunocompromised individuals. Many animals as well as humans could be infected with different isolates of Cryptosporidium spp. in experimental studies ${ }^{3,4}$.

Oocysts in tap water systems were reported to be resistant to disinfectant. Therefore, many water-born outbreaks also occurred due to oocysts in chlorinated water. The outbreak, which occurred in 1989 in the UK some 5,000 people became ill, while in 1993 more than 400,000 people in the USA were affected by an outbreak of Cryptosporidium spp. Cryptosporidium spp. and Giardia intestinalis has been responsible for $71 \%$ of waterborne outbreaks in the $\mathrm{USA}^{11}$. LeChevalier and his colleagues investigated Cryptosporidium oocysts and Giardia cysts in water treatment plants of 14 states in the USA, and reported that in $81 \%$ Cryptosporidium spp. and in $87 \%$ G. intestinalis were present in the untreated water, while $17 \%$ of the filtered water was positive for Cryptosporidium, and $27 \%$ for $\mathrm{G}$. intestinalis.

In Turkey, only one waterborne Cryptosporidium outbreak have been reported from a village near İzmir, where Cryptosporidium spp. was found in $15(8 \%)$ of the villagers ${ }^{6}$.

In Turkey, the first study on Cryptosporidium was conducted in İstanbul by Köksal, and the parasite could not be detected in any of the 40 dam water samples examined by the DFA technique ${ }^{23}$. Çeber and his colleagues reported Cryptosporidium oocysts in $11 \%$ of tap water, sea water and 
waste water samples examined in Mersin by MAF24. Later and in another study in the same province, Cryptosporidium oocysts were detected in $5.2 \%$ of the samples by PCR method ${ }^{25}$. The genotyping of the parasites revealed that they belong to the species C. parvum ${ }^{25}$. Çiçek et al. ${ }^{26-29}$ examined 440 water samples in the Van province by MAF method and found a positivity rate of $13.1 \% 26$. In the present study Cryptosporidium spp. were identified in $2.2 \%$ of the samples. Today, 22 species of Cryptosporidium are known. Earlier, only Cryptosporidium parvum was known in humans. Later, using molecular methods, it was reported that there were two different genotypes of C. parvum, known as Genotype I and II. More recently, two species are known to infect humans: C. parvum and C. hominis. While C. hominis is known only from humans, C. parvum was found also in a number of animals.

Cryptosporidium can be identified in feces, sputum and bile. Several diagnostic methods were used for this purpose; however the molecular diagnostic methods for the detection of the parasite are more sensitive. The diagnosis by staining of the oocysts is difficult due to the decomposition of the oocysts in water samples.

The DFA method when used in conjunction with the immunomagnetic separation method has been shown to increase the chances of finding Cryptosporidium spp. in water samples. Today, DFA kits for diagnosis of Cryptosporidium spp. are commonly used. These kits are suitable also for the diagnosis of G. intestinalis, however there are not able to diagnose to the species level of the Cryptosporidium.

The microscopic diagnosis is usually done by experienced people. The sensitivity and specificity of DFA and ELISA methods are high for the detection of Cryptosporidium antigen. There are two main target antigens of Cryptosporidium with a molecular weight of 15-17 kDa. These are Cp17 (gp 15 ) and $27 \mathrm{kDa}$ antigens, which are also known as $\mathrm{Cp} 23$ antigens. For the isolation of Cryptosporidium from clinical and water samples, filtration, concentration and various gradient methods are being used. Molecular diagnostic methods were first used in 1991 for the diagnosis of Cryptos- poridium30. Oocysts were detected in the water and feces samples using the nested PCR method Combined with PCR, restriction fragment length polymorphism (PCR-RFLP) as well as real-time PCR for the identification of Cryptosporidium spp. are reported to be the most widely used sensitive and specific methods ${ }^{8,25}$.

Acknowledgement: We thank Prof. Dr. Ferda Sevinç University of Selçuk, Faculty of Veterinary, Department of Parasitology, for providing us unpurified Cryptosporidium oocysts, which were obtained from a calf fecal suspension.

\section{REFERENCES}

1. Mosier DA, Oberst RD. Cryptosporidiosis. A global challenge. Ann. N. Y. Acad. Sci 2000; 916: 102-11.

2. Carey CM, Lee H, Trevors JT. Biology, persistence and detection of Cryptosporidium parvum and Cryptosporidium hominis oocyst. Water Res 2004; 38: 818-62.

3. Tzipori S. Cryptosporidiosis in perspective. Adv. Parasitol. 1998; 27: 63-130.

4. Tzipori S, Widmer G. A hundred year retrospective on cryptosporidiosis. Trends Parasitol 2008; 24: 184-9.

5. Fayer R, Morgan UM, Upton SJ. Epidemiology of Cryptosporidium: Transmission, detection, and identification. Int. J. Parasitol 2000; 30: 1305-22.

6. LeChevalier MW, Norton WD, Lee, RG. Occurrence of Giardia and Cryptosporidium spp. in surface water supplies. Appl. Env. Microbiol 1991; 57: 2610-6.

7. Lonigro A, Pollice A, Spinelli R, Berrilli F, Di Cave D, D’Orazi C, Cavallo P, Brandonisio O. Giardia cysts and Cryptosporidium oocysts in membrane-filtered municipal wastewater used for irrigation. Appl. Environ. Microbiol 2006; 72: 7916-8.

8. Dreelin EA, Ives RL, Molloy S, Rose JB. Cryptosporidium and Giardia in surface water: A case study from Michigan, USA to inform management of rural water systems. Int. J. Environ. Res. Public Health 2014; 11: 10480-503.

9. Shepherd KM, Wyn-Jones AP. An 
evaluation of methods for simultaneous detection of Cryptosporidium oocysts and Giardia cysts from water. Appl. Environ. Microbiol 1996; 62: 1317-22.

10. Richardson AJ, Frankenberg RA, Buck AC, Selcon JB, ColbourneJW, Mayon-WhiteRT. An outbreak of waterborne cryptosporidiosis in Swindon and $\mathrm{Ox}$ fordshire. Epidemiol. Infect 1991; 107: 485-95.

11. Mac Kenzie WR, Hoxie NJ, Proctor ME, Gradus MS, Blair KA, Peterson DE, Kazmierczak JJ, Addiss DG, Fox KR, Rose JB. A massive outbreak in Milwaukee of Cryptosporidium infection transmitted through the public water supply. N. Engl. J. Med 1994; 331: 161-7.

12. Gostin LO, Lazzini Z, Neslund VS, Osterholm MT. Water quality laws and waterborne diseases: Cryptosporidium and other emerging pathogens. Am. J. Public Health 2000; 90: 847-9.

13. Widerström M, Schönning C, Lilja M. Large outbreak of Cryptosporidium hominis infection transmitted through the public water supply, Sweden. Emerg. Infec. Dis 2014; 20: 581-9.

14. Aksu U, Akisu C, Sahin S, Usluca S, Yalcin G, Kuralay F, Oral AM. First reported waterborne outbreak of Cryptosporidiosis with Cyclospora co-infection in Turkey. Eurosurveillance 2007; 12.

15. Swaffer BA, Vial HM, King BJ, Daly R, Frizenschaf J, Monis TM. Investigating source water Cryptosporidium concentration, species and infectivity rates during rainfall-runoff in a multi-use catchment. Water Research 2014; 67: 310-20.

16. Graczyk TK, Kacprzak M, Neczaj E, Tamang L, Graczyk H, Lucy EF, Girouard AS. Occurrence of Cryptosporidium and Giardia in sewage sludge and solid waste landfill leachate and quantitative comparative analysis of sanitization treatments on pathogen inactivation. Environ. Research 2008;
106: 27-33.

17. Graczyk TK, Cranfield MR, Fayer R. Evaluation of commercial enzyme immunoassay (EIA) and immunofluorescent antibody (FA) test kits for the detection of Cryptosporidium oocysts of species other than Cryptosporidium parvum. Am. J. Trop. Med. Hyg 1996; 54: 274-9.

18. Watanabe ME. New Cryptosporidium testing methods. Environ. Science Technol 1996; 30: 532.

19. Mayer CL, Palmer CL. Evaluation of PCR, nested PCR, and fluorescent antibodies for detection of Giardia and Cryptosporidium species in wastewater. Appl. Environ. Microbiol 1996; 62: 2081-5.

20. Tanrıverdi S, Tanyeli A, Baslamisli F, Koksal F, Kilic Y, Feng X, Batzer G, Tzipoi S, Widmer G. Detection and genotyping of oocysts of Cryptosporidium parvum by real-time PCR and melting curve analysis. J. Clin. Microbiol 2002; 40: 3237-44.

21. Ward PI, DeplazesP, Regli W, Rinder H, Mathis A. Detection of eight Cryptosporidium genotypes in surface and wastewaters in Europe. Parasitology 2002; 124: 35968.

22. Xiao L, Escalante L, Yang C, Sulaiman I, Escalante IA, Montali RJ, Fayer R, Lal AA. Phylogenetic analysis of Cryptosporidium parasites based on the small-subunit rRNA gene locus. Appl. Environ. Microbiol 1999; 65: 1578-83.

23. Köksal F. Kaynak sularının Giardia ve Cryptosporidium yönünden incelenmesi. Türk. Mikrobiyol. Cem. Derg 2002; 32: 275-7.

24. Çeber K, Aslan G, Otağ F, Delialioğlu N, Öztürk C, Babür C, Emekdaş G. Mersin ilinde içme suyu, kullanma suyu, atık su ve deniz sularında Cryptosporidium spp. ookistlerinin araştırılması. Türkiye Parazitol. Derg 2005; 29: 224-8.

25. Aslan G, Bayram G, Otağ F, Direkel S, Taylan Özkan A, Ceber K, Emekdaş G. Investigation of the 
presence of Cryptosporidium spp. in different water sources in Mersin province, Turkey. Mikrobiyol Bul 2012; 46: 93-100.

26. Çiçek M, Körkoca H, Akkaş Ö. Van ili içme sularının Cryptosporidium spp. yönünden incelenmesi. Türk. Hij. Den. Biyol. Derg 2011; 68: $122-6$.

27. Abrahamsen MS, Templeton TJ, Enomoto S. Complete genome sequence of the apicomplexan, Cryptosporidium parvum. Science 2004; 304:441-5.

28. Xiao, L., Fayer, R., Ryan, U., \& Upton, S. J. Cryptosporidium taxonomy: Recent advances and implications for public health. Clin. Microbiol. Rev. 2004; 17:72-97.

29. Xu P, Widmer G, Wang Y. The genome of Cryptosporidium hominis. Nature 2004; 431:1107-12.

30. Laxer MA, Timblin BK, Patel RJ. DNA sequences for the specific detection of Cryptosporidium parvum by the polymerase chain reaction. Am J Trop Med Hyg. 1991; 45: 688-94. 